\title{
Plant antimicrobial peptides
}

\author{
Robert Nawrot • Jakub Barylski • Grzegorz Nowicki • \\ Justyna Broniarczyk • Waldemar Buchwald • \\ Anna Goździcka-Józefiak
}

Received: 18 April 2013 / Accepted: 17 September 2013 /Published online: 4 October 2013

(C) The Author(s) 2013. This article is published with open access at Springerlink.com

\begin{abstract}
Plant antimicrobial peptides (AMPs) are a component of barrier defense system of plants. They have been isolated from roots, seeds, flowers, stems, and leaves of a wide variety of species and have activities towards phytopathogens, as well as against bacteria pathogenic to humans. Thus, plant AMPs are considered as promising antibiotic compounds with important biotechnological applications. Plant AMPs are grouped into several families and share general features such as positive charge, the presence of disulfide bonds (which stabilize the structure), and the mechanism of action targeting outer membrane structures.
\end{abstract}

$\begin{array}{ll}\text { Abbreviations } \\ \text { aa } & \text { Amino acid(s) } \\ \text { AMP } & \text { Antimicrobial peptide(s) } \\ \text { approx. } & \text { Approximately } \\ \text { CCK } & \text { Cyclic cysteine knot } \\ \text { CPP } & \text { Cell-penetrating peptide(s) } \\ \text { CTR } & \text { C-terminal repeat } \\ \text { ER } & \text { Endoplasmic reticulum } \\ \text { GASA } & \text { Gibberellic acid stimulated in Arabidopsis } \\ \text { GAST } & \text { Gibberellic acid stimulated transcript } \\ \text { kDa } & \text { Kilodalton(s) } \\ \text { McoTI-II } & \text { Momordica cochinensis trypsin inhibitor II } \\ \text { ns-LTP } & \text { Nonspecific lipid transfer protein }\end{array}$

R. Nawrot $(\bowtie) \cdot J$. Barylski · G. Nowicki $\cdot$ J. Broniarczyk A. Goździcka-Józefiak

Department of Molecular Virology, Institute of Experimental Biology, Faculty of Biology, Adam Mickiewicz University in Poznan, Umultowska 89, 61-614 Poznan, Poland

e-mail: rnawrot@amu.edu.pl

W. Buchwald

Institute of Natural Fibres and Medicinal Plants, Kolejowa 2, 62-064 Plewiska, Poland

$\begin{array}{ll}\text { NTR } & \text { N-terminal repeat } \\ \text { PIN } & \text { Puroindoline(s) } \\ \text { PTD } & \text { Protein transduction domain(s) } \\ \text { SFT1 } & \text { Sunflower trypsin inhibitor I } \\ \text { StSN1 } & \text { Snakin1 } \\ \text { StSN2 } & \text { Snakin2 } \\ \text { GAFP } & \text { Ginkgo biloba } \text { antifungal peptide } \\ \text { PAFP-S } & \text { Phytolacca anifungal peptide }\end{array}$

\section{Introduction}

As a part of defense response, plants produce a high number of toxic molecules, including antimicrobial peptides (AMPs), that kill pathogens by interaction with phospholipids and membrane permeabilization. The other group comprises cell-penetrating peptides (CPPs), capable of introducing into cells a variety of cargoes in the absence of specific receptors by interaction at some point with membrane phospholipids. AMPs and CPPs are a part of the nonspecific host defense system and are active against different types of microorganisms (Eudes and Chugh 2008; Rivas et al. 2010; Pelegrini et al. 2011; Hegedus and Marx 2013). Antimicrobial peptides have been described in a wide variety of species including, insects, amphibians, and mammals. They exhibit a wide range of functions ranging from direct antimicrobial properties to immunomodulatory effects (Choi et al. 2012). AMPs have been demonstrated to inactivate prokaryotic cells by targeting a number of essential or metabolic processes at extracellular, plasma membrane, and/or intracellular sites (Yount and Yeaman 2013). Most of the natural antimicrobial peptides are 10 to 50 amino acids (aa) in length, range in size from 2 to $9 \mathrm{kDa}$, are positively charged, contain a high position of hydrophobic amino acid, and often display a helical structure. AMPs are gene-encoded and they are either constitutively expressed or rapidly transcribed upon induction in eukaryotes 
by invading microbes and their products, or host cellular compounds, such as cytokines, butyrate, or vitamins (Schauber et al. 2006; Lai and Gallo 2009). These peptides are categorized into distinct families mainly on the basis of their amino acid sequence, identity, number of cysteine residues, and their spacing (Lay and Anderson 2005). On the basis of their electrical charge, plant AMPs can be divided into anionic (AAMPs) and cationic peptides (CAMPs) (Pelegrini et al. 2011).

Plant antimicrobial peptides has been isolated from roots, seeds, flowers, stems, and leaves from a wide variety of species and have demonstrated activities towards phytopathogens, as well as against organisms pathogenic to human, viruses, bacteria, fungi, protozoa, parasites, and neoplastic cells (Montesinos 2007). The repertoire of AMPs synthesized by plants is extremely large with hundreds of different AMPs in some plant species. The main families of AMPs comprise defensins, thionins, lipid transfer proteins, cyclotides, snakins, and hevein-like proteins, according to amino acid sequence homology.

\section{Structural and functional relationships of plant AMPs}

Primary and tertiary structure comparison of plant AMPs

In silico analyses revealed some similarities in tertiary structures of plant AMPs, despite significant differences in amino acid sequences between the families (Pelegrini et al. 2011; Fig. 1). Key features of AMPs are high content of cysteine and/or glycine and the presence of disulphide bridges, which are important for enhancing structural stability under stress conditions. Around $17 \%$ of the amino acids in plant AMPs are charged (mainly ariginines and/or lysines, but also aspartic acid and glutamic acid), what seems to play an essential role in activity towards pathogenic bacteria (Hammami et al. 2009; Pelegrini et al. 2011).

Mechanism of antibacterial and antifungal action of plant AMPs

Most of the known AMPs act by formation of membrane pores, resulting in ion and metabolite leakage, depolarization, interruption of the respiratory processes, and cell death (Pelegrini et al. 2011). Amphipathic structure and positive charge at physiological $\mathrm{pH}$ may be significant features allowing AMPs to interact with membrane lipids. The cationic residues electrostatically attract negatively charged molecules (e.g., anionic phospholipids, lipopolysaccharides, or teichoic acids) allowing the peptide to accumulate on the membrane surface (Pelegrini and Franco 2005). When concentration reaches a threshold value, the collapse begins. Three main models explaining this phenomenon were proposed (Fig. 2): barrel-stave model, the wormhole (or toroid pore) model, and carpet model. In the

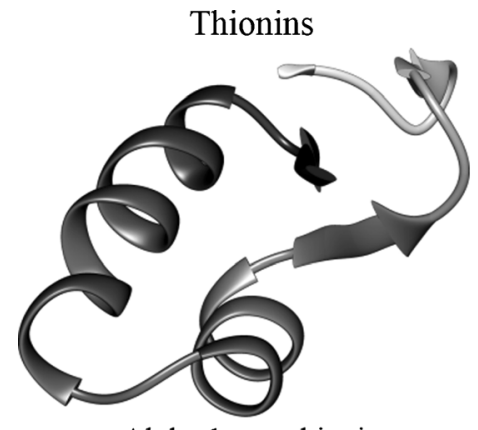

Alpha 1-purothionin

(Triticum aestivum)

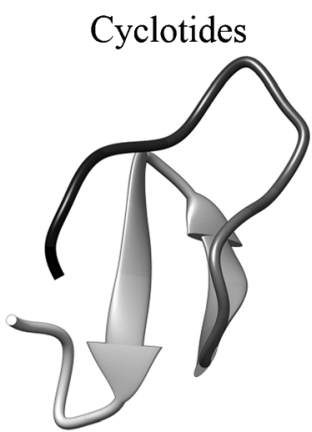

Kalata B1

(Oldenlandia affinis)

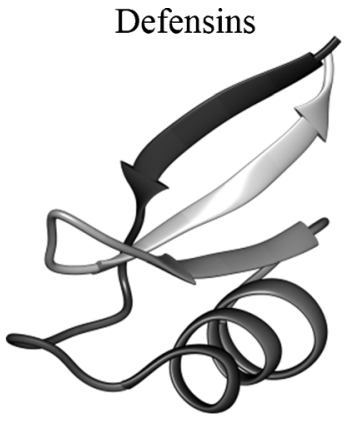

Defensin 2

(Vigna radiata)

Hevein-like proteins

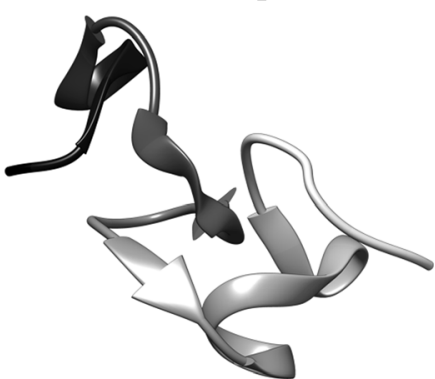

Hevein

(Hevea brasiliensis)
Lipid transfer proteins

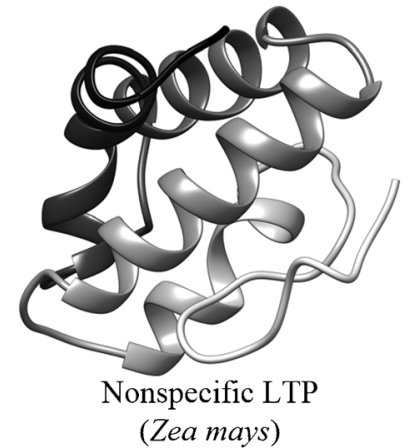

Knottin-type peptides

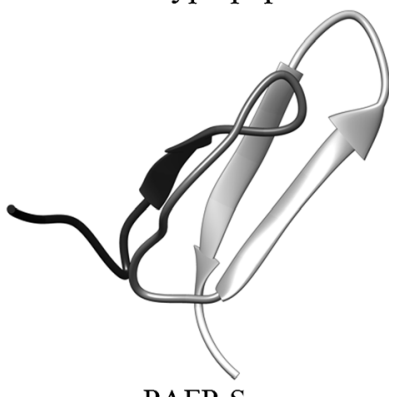

PAFP-S

(Phytolacca americana)
Fig. 1 Three-dimensional structures of selected antimicrobial peptides from different families. The structures were retrieved from RCSB Protein Databank and visualized with UCSF Chimera package (Resource for
Biocomputing, Visualization, and Informatics; University of California) (Pettersen et al. 2004) 


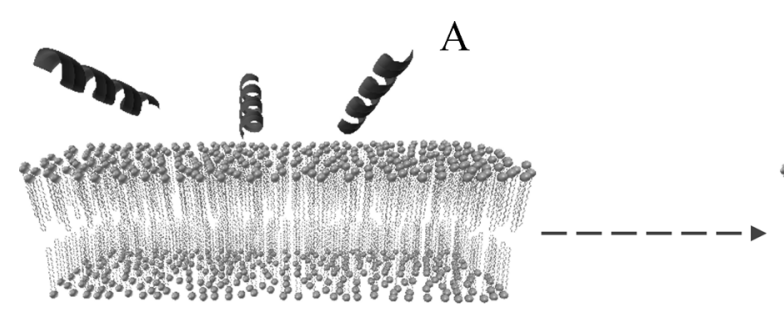

B

D

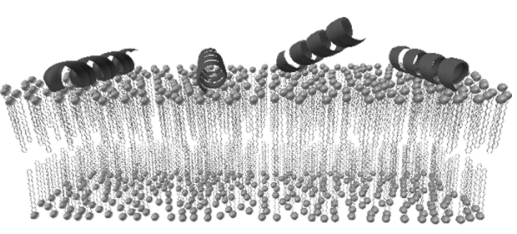

C

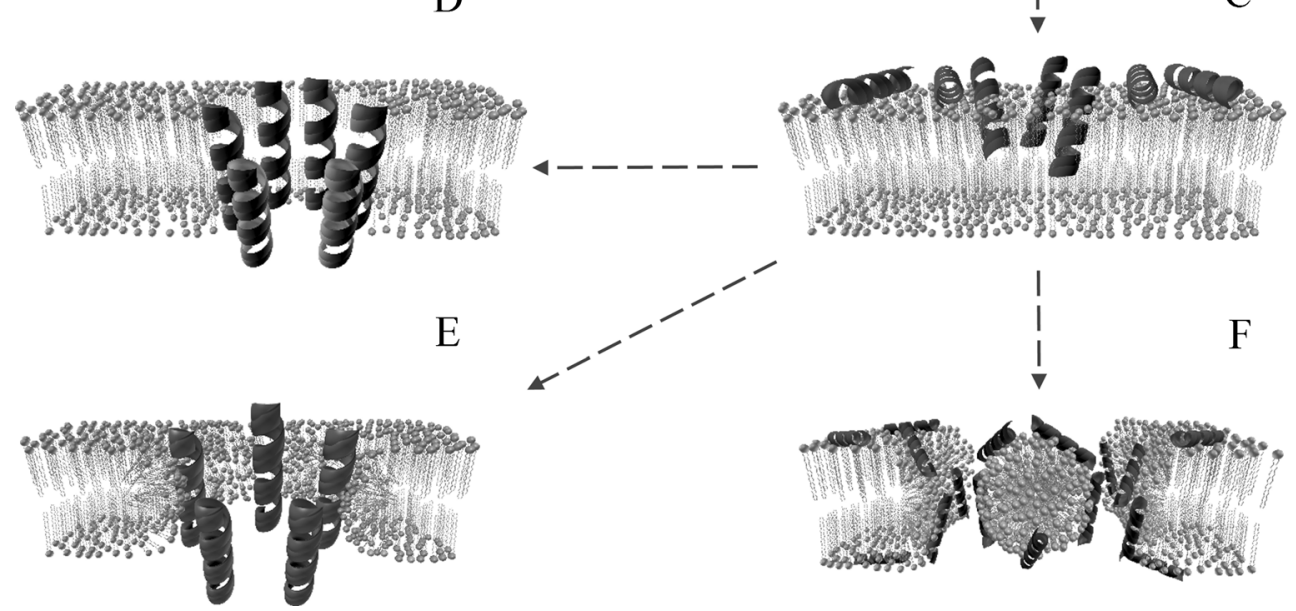

Fig. 2 Frequently cited models for activity of antimicrobial peptides. a AMPs diffusing through solution, $\mathbf{b}$ AMPs adsorption to the membrane. After the threshold concentration is achieved, peptide molecules begin to reorient in the lipid bilayer $(\mathbf{c})$. Their further fate may be described using one of three models. The first, depicted in the $\mathbf{d}$ is called barrel-stave model. In this scenario, hydrophobic regions of AMPs align with the tails of the lipids and the hydrophilic residues form the inner surface of the

forming pore. According to the wormhole model (called also toroidal pore model, shown in e) during peptides aggregation, hydrophilic heads of the lipids are electrostatically dragged by charged residues of AMPs. The membrane bends, two layers merge and form continuous surface surrounding the pore. The carpet model shown in $\mathbf{f}$ assumes, that at large concentrations, peptide molecules disrupt the membrane in a detergentlike manner breaking the lipid bilayer into set of separate micelles

barrel-stave mechanism, AMPs oligomerize with hydrophobic residues of peptide facing interior of the lipid bilayer and hydrophilic ones oriented towards the lumen of newly formed pore. In the wormhole mechanism, peptide molecules reorient in the membrane during the aggregation dragging of the lipids with them (through electrostatic interactions between head groups of phospholipids and hydrophilic residues of AMPs). Consequently, the membrane is "bend" and joined layers form the toroidal pore. In the carpet mechanism, peptides act like detergents, covering the membrane in an electrostatic manner (in monomeric or oligomeric form). This "carpet" of amphipatic molecules causes a phospholipid displacement, alters membrane properties, and disrupts the membrane (Pelegrini et al. 2011). There are some other models such as the sinking raft model (Pokorny and Almeida 2004), aggregate model (Wu et al. 1999), or the molecular electroporation (Miteva et al. 1999); however, they have not received much attention in the field, are rarely cited, and have not found much experimental confirmation.

There are some differences between antifungal and antibacterial activity, mainly connected with different composition of the target membrane. For example, $\gamma$-thionins might bind

to glucosylceramides and sphingolipids in fungal membrane (instead of phospholipids being their receptors in bacteria; Pelegrini and Franco 2005). However, many AMPs (e.g., $\gamma$ thionin SI $\alpha 1$ from Sorghum bicolor) show activity toward both bacteria and fungi (Hughes et al. 2000; Pelegrini and Franco 2005).

In terms of specificity of plant AMPs-pathogen interactions, still a lot remains unclear. Nevertheless, specific residues could be connected with thionins activity towards different groups of organisms. For example, A2 $\gamma$-thionin from Pyrularia pubera (Pp-TH) contains aspartic residue at the position 32 instead of arginine, commonly found in other $\gamma$-thionins. The presence of Asp32 was shown to be important for in vitro activity against diverse Gram-negative bacteria (Rhizobium melioti and Xanthomonas campestris) and numerous fungi (Fusarium oxysporum, Plectosphaerella cucumerina, and Botritis cinerea; Villa-Perello et al. 2003; Pelegrini and Franco 2005). Site-directed mutagenesis studies performed to produce new variants of Rs-AFP1 defensin revealed that a variant in which Gly9 or Val39 was replaced with arginine was more active against certain fungi than wild-type Rs-AFP2 (Lay and Anderson 2005). 


\section{Detailed description of main families of plant AMPs}

\section{Thionins}

Thionins are a family of antimicrobial peptides with low molecular weight (about $5 \mathrm{kDa}$ ), rich in arginine, lysine, and cysteine residues. Their structure includes two antiparallel $\alpha$ helices and an antiparallel double-stranded $\beta$-sheet with three or four conserved disulfide linkages. They are positively charged at neutral $\mathrm{pH}$. The groove between the $\alpha$-helices and $\beta$-sheets posses the Tyr 13 residue, the membrane interactions of which may be associated with cell leakage which appears to be a common mechanism of cell lysis of thionins (Majewski and Stec 2001). Thionins are toxic against bacteria, fungi, and yeast (Table 1). Around 100 individual thionin sequences have been identified in more than 15 different plant species (in monocots, dicotyledonous, and rosids; Stec 2006). The first thionin was isolated in 1942 by Balls and collaborators from wheat endosperm Triticum aestivum, later called purothionin (Mak and Jones 1976). The name thionins is used for two distinct groups of plant peptides: $\alpha$-/ $\beta$-thionins and $\gamma$ thionins. The last group ( $\gamma$-thionins) have much more in common with a large family of membrane active peptides called defensins, found in plants and animals (Stotz et al. 2009). Thionins have a common gene structure with an $~ 20$ aa-long leader peptide and an $\sim 60$ aa-long trailing acid peptide, which neutralizes the basic toxin (Stec 2006). Cleavage of the leader peptide is necessary for toxin activation. All thionins are present in almost every crucial plant tissue from endosperm to leaves. Their toxic effect was postulated to arise from lysis of the membranes of attaching cells. The precise mechanism underlying toxicity remains unknown. Antifungal activity of thionins is a result of direct protein-membrane interactions by electrostatic interaction of the positively charged thionin with the negatively charged phospholipids in fungal membranes, and this result in pore formation or a specific interaction with a certain lipid domain (De Lucca et al. 2005). $\alpha$-/ $\beta$-thionins are subdivided into five classes; however, all types appear highly homologous at the amino acid level (Stec 2006).

\section{Types I and II thionins}

Type I thionins (purothionins) are present in the endosperm of grains (the family Poaceae), are highly basic, and consist of 45 amino acids, 8 of which are cysteins. Type II thionins $(\alpha-$ hordothionin and $\beta$-hordothionin) are slightly less basic than type I, consists of 46-47 amino acids, and were isolated from leaves and nuts of the plant $P$. pubera (Vernon 1992). Types I and II thionins have four disulfide bonds.
Table 1 Antimicrobial properties of selected thionins

\begin{tabular}{|c|c|c|}
\hline Protein & Susceptible species & References \\
\hline Wheat endosperm crude purothionin & $\begin{array}{l}\text { Bacteria: } \\
\text { Pseudomonas solanacearum } \\
\text { Xanthomonas phaseoli } \\
\text { Xanthomonas campestris } \\
\text { Erwinia amylovora } \\
\text { Corynebacterium fascians } \\
\text { C. flaccumfaciens } \\
\text { C. michiganese } \\
\text { C. poinsettiae } \\
\text { C. sepedonicum }\end{array}$ & $\begin{array}{l}\text { Fernandez De Caleya et al. } \\
\text { (1972) }\end{array}$ \\
\hline Wheat endosperm $\alpha$-purothionin & $\begin{array}{l}\text { Fungi: } \\
\text { Rhizoctonia solani }\end{array}$ & Oard et al. (2004) \\
\hline $\begin{array}{l}\text { Viscotoxin A3 and B from leaves } \\
\text { and stems of Viscum album L. }\end{array}$ & $\begin{array}{l}\text { Fungi: } \\
\text { Fusarium solani } \\
\text { Sclerotinia sclerotiorum } \\
\text { Phytophtora infestans }\end{array}$ & Giudici et al. (2004) \\
\hline Nicotiana attenuate PR-13 thionins & $\begin{array}{l}\text { Bacteria: } \\
\text { Pseudomonas syringae pv. } \\
\quad \text { tomato }\end{array}$ & Rayapuram et al. (2008) \\
\hline Pearl millet seed thionin & $\begin{array}{l}\text { Fungi: } \\
\text { Sclerospora graminicola }\end{array}$ & Chandrashekhara et al. (2010) \\
\hline $\begin{array}{l}\text { WBeta (thionin) from Triticum } \\
\text { aestivum }\end{array}$ & $\begin{array}{l}\text { Fungi: } \\
\text { Fusarium solani }\end{array}$ & Terras et al. ( 1993a, b) \\
\hline AX1 thionin from Beta vulgaris & $\begin{array}{l}\text { Fungi: } \\
\text { Cercospora beticola }\end{array}$ & Kragh et al. (1995) \\
\hline
\end{tabular}




\section{Type III thionins}

Type III thionins have 45-46 amino acids and three disulfide bridges and are as basic as type II thionins. They were isolated from the leaves and stems of mistletoe species, such as Viscum album (viscotoxins A1, A2, A3, B, B2, 1-PS, UPS, C1), Phoradendron tomentosum phoratoxins A, B), Phoradendron liga (ligatoxin A), and Dendrophthora clavata (Samuelsson and Pettersson 1970, 1977; Thunberg and Samuelsson 1982).

\section{Type IV thionins}

Type IV thionins (crambins) consist of 46 amino acids and three disulfide bonds. Crambin has no charge at neutreal $\mathrm{pH}$ and its helices have a significant hydrophobic character. Despite overall hydrophobic character (neutral charge), crambin is amphipathic with two Arg residues. They were isolated from seeds of Crambe abyssinica (Abyssinian cabbage; Schrader-Fisher and Apel 1994).

\section{Type V thionins}

Type $\mathrm{V}$ thionins are truncated forms of thionins found in some grains like wheat. Hellothionin D isolated from roots of Helleborus purpurascens belongs to this group (Milbradt et al. 2003).

One of the best structurally studied proteins is Viscotoxin isolated from leaves and stems of European mistletoe $(V$. album). This thionin is toxic against a various number of cells, particularly against tumoral cells. These peptides induce the appearance of imperfections on the surface of membranes that lead to the destabilization and disruption of the membrane bilayer (Stec 2006). From the endosperm of wheat seeds betapurothionin was isolated, which assume inserts into the hydrophobic core of the lipid layer (Stec 2006). $\alpha$-(1)Purothionin is a wheat germ protein and a basic lytic toxin. Thionins are included in the pathogenesis-related (PR) proteins as the PR-13 group (Epple et al. 1995).

\section{Defensins}

The first plant defensins were isolated from wheat T. aestivum and barley Hordeum vulgare and initially classified as $\gamma$ thionins. Plant defensins are small (ca. $5 \mathrm{kDa}$ ), basic, cysteine-rich peptides ranging from 45 to 54 amino acids, and are positively charged. Biological activities reported for plant defensins include antifungal, antibacterial, proteinase, and insect amylase inhibitor activities (Table 2; Wijaya et al. 2000; Stotz et al. 2009). The plant defensins have quite diverse amino acid composition and conserved threedimensional structure, which comprises a triple-stranded $\beta$ sheet with an $\alpha$-helix in parallel stabilized by four disulfide bridges. Plant defensins are very similar to defense peptides of mammals and insects what suggest their ancient and conserved origin. Generally, plant defensins are composed by one subunit, being found in monomeric forms. On the other hand, the defensins from Pachyrrhizus erosus and other from Vigna unguiculata showed the ability to dimerism (Pelegrini and Franco 2005). The mode of action of plant defensins is still unclear and not all plant defensins have the same mode of action. Probable defensins used glucosylceramides as receptors for fungi cell membrane insertion. Then, repulsion of defensins into cell membrane by their positive charges leads to membrane disruption, membrane destabilization, and ion efflux (Pelegrini and Franco 2005). Plant defensins can be divided in two groups: (1) plant defensins that inhibit fungal growth through morphological distortions of the fungal hyphae and (2) plant defensins that inhibit fungal growth without morphological distortion (Hegedus and Marx 2013). Most plant defensins were isolated from seeds. In radish, defensin RS-AFPs represents $0.5 \%$ of total protein in seeds. Defensins were also isolated from leaves, pods, tubers, fruits, roots, bark, and floral organs of such plants as Heuchera sanguinea (Hs-AFp1), Raphanus sativus (Rs-AFP1), Aesculus hippocastanum (AhAMP1), Dahlia merckii (Dm-AMP1), and Clitoria ternatea (Ct-AMP1; De Lucca et al. 2005). Defensins are expressed during normal plant growth and development and induced by environmental factors and biotic and abiotic stress (PestanaCalsa and Calsa 2011). The defensins gene induced upon pathogen infection has been identified in pea, tobacco, Arabidopsis, and spruce (Lay and Anderson 2005).

Two classes of defensins are produced. The first class, the precursor protein, contains an amino signal peptide that targets the peptide to the extracellular space. The second class of defensins have $\mathrm{C}$-terminal prodomains.

Plant defensins are best known for their antimicrobial activity against a broad spectrum of plant pathogens as bacteria, yeast, oomycetes, and necrotrophic pathogens (Segura et al. 1998; Portieles et al. 2010; van der Weerden et al. 2010). They also show activities important for medical applications as anticancer activity and antiviral activity (Ngai and $\mathrm{Ng}$ 2005; Wong and Ng 2005). Plant defensins interact with glucosylceramides in membranes of susceptible yeast and fungi and induce membrane permeabilization and fungal cell death (Thevissen et al. 1996, 2004).

$\gamma$-Hordothionin belongs to plant defensins (molecular weight, 5,250 Da; contains four disulfide bridges), which inhibits translation in cell-free systems. The others are defensin PhD1 from Petunia hybrida with antifungal activity and defensins 1 and $2(\mathrm{VrD} 1$ and $\mathrm{VrD} 2)$ isolated from the seeds of the mung bean, Vigna radiata (Padovan et al. 2010). However, only $\operatorname{VrD} 1$ exhibits insecticidal activity and $\alpha$ amylase inhibitory activity. $\mathrm{PhD} 1$ has 47 residues and five disulfide bonds. Other features of plant defensins are related to the regulation of growth, development, and fertilization (Oomen et al. 2011). 
Table 2 Antimicrobial properties of selected plant defensins

\begin{tabular}{|c|c|c|}
\hline Defensin & Susceptible species & Reference \\
\hline MsDef1 from Medicago sativa & $\begin{array}{l}\text { Fungi: } \\
\text { Magnaporthe grisea } \\
\text { Erwinia carotovora } \\
\text { Botrytis cinerea }\end{array}$ & Spelbrink et al. (2004) \\
\hline WT 1 from Wasabia japonica L. & $\begin{array}{l}\text { Fungi: } \\
\text { Magnaporthe oryzae } \\
\text { Rizoctonia solani }\end{array}$ & Lay and Anderson (2005) \\
\hline Dm-AMP1 from dahlia & $\begin{array}{l}\text { Fungi: } \\
\text { Fusarium culmorum }\end{array}$ & Zhu et al. (2007) \\
\hline Ah-AMP1 from Aesculus hippocastanum & $\begin{array}{l}\text { Fungi: } \\
\text { Fusarium moniliforme }\end{array}$ & Terras et al. (1993a, b) \\
\hline Rs-AFP1 from Raphanus sativus & $\begin{array}{l}\text { Fungi: } \\
\text { Fusarium culmorum } \\
\text { Botritis cinerea }\end{array}$ & De Lucca et al. (1999) \\
\hline RsAFP2 from Raphanus sativus & $\begin{array}{l}\text { Fungi: } \\
\text { Baker's yeast } \\
\text { Candida albicans }\end{array}$ & Thevissen et al. (2012) \\
\hline $\begin{array}{l}\text { Hc-AFP1 Hc-AFP2 HcAFP3 Hc-AFP4 } \\
\text { from Heliophila coronopifolia }\end{array}$ & $\begin{array}{l}\text { Fungi: } \\
\text { Botrytis cinerea } \\
\text { Fusarium solani }\end{array}$ & De Beer and Viver (2011) \\
\hline HsAFP1 from Heuchera sanguinea & $\begin{array}{l}\text { Fungi: } \\
\text { Aspergillus flavus } \\
\text { Candida albicans } \\
\text { Candida krusei }\end{array}$ & Thevissen et al. (2007) \\
\hline Ns-D1 Ns-D2 from Nigella sativa seeds & $\begin{array}{l}\text { Fungi: } \\
\text { Aspergillus niger } \\
\text { Fusarium oxysporum } \\
\text { Fusarium graminearum } \\
\text { Fusarium culmorum } \\
\text { Bipolaris sorokiniana } \\
\text { Botritis cinerea }\end{array}$ & Rogozhin et al. (2011) \\
\hline
\end{tabular}

Lipid transfer proteins

In various monocotyledonous and dicotyledonous plant species, the nonspecific small lipid transfer proteins (ns-LTPs) are present that are capable of exchanging lipids between membranes in vitro. ns-LTPs participate in membrane biogenesis; regulation of the intracellular fatty acid pools; involved in defense reactions against phytopathogens, cutin formation, embryogenesis, and symbiosis; and the adaptation of plants to various environmental conditions. Their antifungal mode of action is not yet known. ns-LTP may insert themselves in fungal membranes and form a pore resulting in an efflux of intracellular ions culminating in cell death (Selitrennikoff 2001). All LTPs share a common structural architecture of a hydrophobic cavity enclosed by four $\alpha$-helices, held in a compact fold by four disulfide bonds (Yeats and Rose 2008).

LTPs bind a large range of lipid molecules to their hydrophobic cavity. These proteins are divided into two subfamilies with relative molecular masses of $9 \mathrm{kDa}$ (LTP1s) and $7 \mathrm{kDa}$ (LTP2s) and they exhibit low overall amino acid sequence similarity (about $30 \%$ ). The N-terminal sequence of the $9 \mathrm{kDa}$ ns-LTP show a high homology, both between dicots and monocots, conservation of a specific Val, near-complete conservation of certain Gly, Ser and proresidues, and conservation of hydrophobic residues at specific sites (Yeats and Rose 2008). Almost all ns-LTPs lack tryptophan residues, except for a few isoforms in Arabidopsis and rice that have 1-2 Trp. LTPs were isolated from young aerial organs of Nicotiana tabacum, as well as mung bean and rice. A number of ns-LTPs exhibit antibacterial and antifungal properties in vitro, hence have been classified as the class PR14 of the pathogenesis-related proteins. Some of ns-LTPs are important allergens in fruits, vegetables, nuts, pollen, and latex (Egger et al. 2010). The ns-LTP from Chinese cabbage, CaNbp10, was found to be a calmodulin-binding protein, regulated by phosphorylation in calcium-dependent manner. CaMbinding domain is localized at the $\mathrm{C}$-terminal region of this 
protein ( $\mathrm{Li}$ et al. 2011). Most of these proteins causing $50 \%$ inhibition (EC 50) were in the range of $0.1-1 \mathrm{mmol} / \mathrm{L}$ for bacterial pathogen (Clavibacter michiganensis and Pseudomonas solanacearum) and close to $10 \mathrm{mmol} / \mathrm{L}$ for the fungal pathogen (Fusarium solani; Table 3).

\section{Puroindolines}

The puroindolines are small basic proteins and contain a unique tryptophan-rich domain. These proteins were isolated from wheat endosperm. They have molecular masses around $13 \mathrm{kDa}$ and contain five disulfide bridges. There are at least two major isoforms called puroindoline (PIN)-a and PIN-b which are encoded by the Pina-D1 and Pinb-D1 genes, respectively. Both proteins contain a backbone of ten conserved Cys residues with a tertiary structure similar to that of LTPs comprised of four $\alpha$ helices separated by loops of variable lengths, with the tertiary structure held together by five disulphide bridges. Four of them are identical to those in ns-LTPs and the fifth is present in PINs due to the two additional Cys (Gautier et al. 1994). PINs contain cations monovalent and also a unique amphiphilic tryptophanrich domain that is not found in the ns-LTPs. The Trp residues occupy a surface loop and form probably the membrane lipidbinding site. The puroindolines are the functional components of the wheat grain hardness locus, control kernel texture, and have antifungal activity (Bhave and Morris 2008; Giroux et al. 2003; Dhatwalia et al. 2009; Zhang et al. 2011).

The antimicrobial activity of PINs is related to interactions with cellular membranes (Table 4). Charnet et al. indicated that PIN-1 is able to form ion channels in artificial and biological membranes which display some selectivity toward monovalent cations. The voltage and $\mathrm{Ca}^{2+}$ ions modulate channels formation and/or opening (Charnet et al. 2003). Puroindolines may also be membranotoxins that might play a role in the defense mechanism of plants against microbial pathogens.

\section{Snakins}

Peptides called snakins have been isolated from potato tubers. They comprise the cell wall-associated peptide snakin-1 (StSN1)
Table 3 Antimicrobial properties of selected ns-LTPs

\begin{tabular}{|c|c|c|}
\hline Ns-LTP & Susceptible species & Reference \\
\hline \multirow[t]{2}{*}{ Ace-AMP1 from Allium cepa } & Fungi: & Cammue et al. (1995) \\
\hline & $\begin{array}{l}\text { Fusarium oxysporum } \\
\text { Fungi: }\end{array}$ & Molina et al. (1993) \\
\hline Cw18 from Hordeum vulgare & $\begin{array}{l}\text { Fusarium solani } \\
\text { Fungi: }\end{array}$ & Segura et al. (1993) \\
\hline $\begin{array}{l}\text { From the leaves of Columbia } \\
\text { wild-type Arabidopsis }\end{array}$ & $\begin{array}{l}\text { Fusarium solani } \\
\text { Bacteria: }\end{array}$ & \\
\hline LTP-s1 LTP-s2 from spinach & $\begin{array}{l}\text { Clavibacter michiganensis subsp. } \\
\text { sepedonicus }\end{array}$ & \\
\hline \multirow[t]{5}{*}{ Ca-LTP(1) } & $\begin{array}{l}\text { Pseudomonas solanacearum } \\
\text { Fungi: }\end{array}$ & Diz et al. (2011) \\
\hline & Colletotrichum lindemuthianum & \\
\hline & Candida tropicalis & \\
\hline & Other activity: & \\
\hline & Inhibitor of mammalian $\alpha$-amylase & \\
\hline \multirow{4}{*}{$\begin{array}{l}\text { Cc-LTP-1 from Coffea } \\
\text { canephora seeds }\end{array}$} & Fungi: & Zottich et al. (2011) \\
\hline & Candida albicans & \\
\hline & Candida tropicalis & \\
\hline & Other activity: & \\
\hline \multirow[t]{8}{*}{ LTP protein from wheat (Sumai3) } & $\begin{array}{l}\text { Inhibitor of mammalian } \alpha \text {-amylase } \\
\text { Fungi: }\end{array}$ & Kirubakaren et al. (2008) \\
\hline & Rhizoctonia solani & \\
\hline & Curvularia lunata & \\
\hline & Alternaria sp. & \\
\hline & Bipolaris oryzae & \\
\hline & Cylindrocladium scoparium & \\
\hline & Botritis cinerea & \\
\hline & Sarocladium oryzae & \\
\hline AceAMP1 LTP from onion seeds & Antifungal and antibacterial & Cheng et al. (2011) \\
\hline
\end{tabular}


Table 4 Antimicrobial properties of selected puroindolines (PINs)

\begin{tabular}{lll}
\hline Puroindoline & Susceptible species & Reference \\
\hline PINA and PINB from wheat & Fungi: & Marion et al. (2007) \\
& Alternaria brassicola & Dubreil et al. (1998) \\
& Ascophyta pisi & Zhang et al. (2011) \\
& Botrytis cinerea & \\
& Verticillium dahliae & \\
& Fusarium culmorum & \\
& Cochliobolus heterostrophus & Jing et al. (2003) \\
PINA from wheat & Bacteria: & \\
& Erwinia amylovora & Dhatwalia et al. (2009) \\
From wheat flour Triticum aestivum L. & Bacteria: & \\
& Staphylococcus aureus & \\
& Microcococcus luteus & \\
& Klebsiella sp. & \\
& Bacillus cereus & \\
\hline
\end{tabular}

and snakin-2 (StSN2), which are antimicrobial peptides with 63 amino acid residues (Table 5; $6.9 \mathrm{kDa}$ ). These peptides show only $38 \%$ sequence similarity and have identical antimicrobial activity against bacterial and fungal pathogens of different plant species. Homologous peptides have been isolated from other plant species. All snakins have 12 conserved cysteine residues and six disulfide bonds (Segura et al. 1999). The mechanism of action of snakins is not known. They do not interact with artificial lipid membranes. The StSN1 gene from potato is constitutively expressed in different tissues during development and does not respond to abiotic or biotic stress. The expression of the StSN2 is locally induced by wounding and shows differential

Table 5 Antimicrobial properties of selected snakins

\begin{tabular}{llr}
\hline Snakins & Susceptible species & References \\
\hline Snakins (StSN1 and & Fungi: & Berrocal-Lobo \\
StSN2) from potato & Botrytis cinerea & et al. (2002) \\
S. tuberosum cv & Fusarium solani & \\
Jaerla & Fusarium culmorum & \\
& Fusarium oxysporum & f.sp conglutinans \\
& Fusarium oxysporum & \\
& f.sp lycopersici & \\
& Plectosphaerella cucumerina & \\
& Colletotrichum graminicola & \\
& Colletotrichum lagenarium & \\
& Bipolaris maydis & \\
& Aspergillus flavus \\
& Bacteria: \\
& Clavibacter michiganensis \\
& Ralstonia solanacearum \\
& Ervinia chrysanthemi \\
& Rhizobium meliloti \\
\end{tabular}

${ }^{\text {a }}$ Not active at concentration: $<20 \mathrm{mmol} / \mathrm{L}$

${ }^{\mathrm{b}}$ Not tested for StSN1 responses to pathogen infection. The snakin peptides are basic and rich in Cys residues, which may form six disulphide bridges that stabilize their structure (Berrocal-Lobo et al. 2002).

StSN1 amino acid sequence alignments show similarity with members of the tomato GAST family (gibberellic acid stimulated transcript) and Arabidopsis GASA family (gibberellic acid stimulated in Arabidopsis) and it was classified as a member of snaking/GASA family (Almasia et al. 2010). Homologous genes have been identified in a wide range of species within monocotyledonous and dicotyledonous plants (Almasia et al. 2010). Snakin/GASA genes encode small proteins in which three distinct domains can be defined: a putative signal peptide of 18-29 residues, a variable region displaying high divergence between family members, both in amino acid composition and sequence length, and a $\mathrm{C}$-terminal region of $\sim 60$ aa containing 12 cysteine residues in conserved positions named GASA domain (Nahirñak et al. 2012).

Snakin/GASA proteins are expressed in different plant organs. Their functions are not completely elucidated and little is known about their mode of action. Most of Snakin/GASA genes are regulated by plant hormones and participate in hormonal signaling pathways modulating hormonal levels and responses (Nahirñak et al. 2012). Members of this family are also implied in diverse processes including defense, cell division, cell elongation, and transition to flowering.

Cyclotides

The cyclotides are group of naturally occurring circular proteins that have been discovered in bacteria, plants, and animals (Pelegrini et al. 2007; Craik 2010). Cyclotides appear to have high sequence similarities and a structural identity. Plant cyclotides comprise 28-37 amino acids, contain a head-to-tail cyclised backbone, and three intramolecular disulfide bonds 
arranged in a cysteine backbone knot topology (cyclic cysteine knot, CCK). The cysteine knot is formed by the disulfide bonds Cys-1-Cys-4 and Cys-2-Cys-5 and their interconnecting backbone form a ring that is penetrated by Cys-3-Cys-6 disulfide bonds (Colgrave and Craik 2004). CCK is largely responsible for the exceptional stability of cyclotides. It forces the hydrophobic parts of the protein to be exposed at the molecular surface. The hydrophobic residues form a patch on the surface, making the overall structure amphipathic (Pränting et al. 2010). They are resilient to various proteolytic and degradative processes (Ireland et al. 2010). The cyclotide structures contain six backbone loops between the conserved Cys residues and different degrees of sequence diversity in the different loops (Ireland et al. 2010). For example, loops 1 and 4 are highly conserved in both size and residue type, whereas the other loops are more variable. Cyclotides were isolated from the plants belonging to family Violaceae, Rubiaceae, Cucurbitaceae, and Poaceae belong to Asterids, Rosids, and Monocots (Gruber 2010). Based on structural similarities, cyclotides are divided into two subfamilies: Mobius and the bracelets based on the presence or absence of a cis-proline, respectively (Craik et al. 1999). Another type of cyclotide structure has katata B8 isolated from Oldenlandia affinis. It appears to be a hybrid between Mobius and bracelet subfamilies (Pelegrini et al. 2007). The plant cyclotides are geneencoded peptides generated via ribosomal biosynthetic pathways. The cyclotide precursor contains an endoplasmic reticulum ER signal, a pro-region, an N-terminal repeat (NTR), and a cyclotide sequence domain, followed by a short tail (Craik 2010). Individual cyclotide genes encode between one and three repeats of the NTR and cyclotide domain to form multiple cyclotide from a single precursor.

The NTR region has the amphipathic helical nature and might assist in directing the connect folding of the cyclotide domain (Ireland et al. 2010). The role of C-terminal region (CTR) is unclear. The conserved Asn (or Asp) residue in this region suggests that this part of protein is a target of an asparaginyl endoproteinase. The first described cyclotide kalata
B1 was isolated from the plant $O$. affinis (Mylne et al. 2010). Kalata B1 was used by women in Africa to accelerate labor and childbirth. These peptides have a diverse range of biological activities, including uterotonic, anti-HIV, antimicrobial, insecticidal, antihelmintic, and molluscidal properties (Table 6; Craik 2010). Their natural function appears to be as plant defense molecules based on their insecticidal properties (Gruber 2010). Thus, cyclotides have potential applications in both the pharmaceutical and agricultural industries. The cyclotides Vitri isolated from Viola tricolor demonstrated cytotoxicity to human lymphoma and myeloma cells. Similarly, cycloviolacin H4 isolated from Viola hederaceae is able to cause hemolysis in human erythrocytes (Pelegrini et al. 2007). It has been suggested that membrane interactions might be involved in the various biological activities of cyclotides; however, the mechanism of their action remains unknown. These proteins have specific membrane-disrupting activity (Svangård et al. 2007; Burman et al. 2011). Kalata B1 interacts directly with the membrane by targeting phosphatidylethanolamine phospholipids, probably leading to membrane bending and vesicle formation. This protein together with cyclotide Momordica cochinensis trypsin inhibitor II (McoTI-II) extracted from seeds and sunflower trypsin inhibitor I (SFT1) from seeds belong also to cyclic cell-penetrating peptides CCPs (Greewood et al. 2007). McoTI-II has been reported to be internalized into cells by macropinocytosis, probably by interacting with phosphatidylinositides and phosphatidic acid, but the specific mechanism by which this occurs is not known (Cascales et al. 2011). The mechanism of penetration of SFTI-1 across the plasma membrane of living cell remains unresolved but is independent of phospholipid and differs from McoTI-II and kalata B1 (Greewood et al. 2007).

\section{Hevein-like proteins}

Hevein is a small $4.7 \mathrm{kDa}$, cysteine-rich, chitin-binding peptide present in the lutoid bodies of rubber tree Hevea brasiliensis
Table 6 Biological activity of selected cyclotides

\begin{tabular}{lll}
\hline Cyclotide & Activity & References \\
\hline Kalata B1 from Oldenlandia affinis & $\begin{array}{c}\text { Insecticidal, molluscidal, hemolytic, } \\
\text { nematocidal, antibacterial, anti-HIV }\end{array}$ & $\begin{array}{l}\text { Jennings et al. (2001) } \\
\text { Plan et al. (2008) } \\
\end{array}$ \\
& & $\begin{array}{l}\text { Daly et al. (2004) } \\
\text { Craik (2012) }\end{array}$ \\
Kalata B2 from Oldenlandia affinis & Insecticidal, molluscicidal, & Plan et al. (2008) \\
& nematocidal, antibacterial, & Ovesen et al. (2011) \\
Cyrulin A\&B from Chassalia parviflora & Hemolytic, antibacterial, anti-HIV & Craik (2012) \\
cycloviolacin O1 from Viola odorata & Nematocidal, molluscidal & Gustafson et al. (1994) \\
Cycloviolacin O2 from Viola odorata & Gram-negative bacteria & Craik et al. (2006) \\
MCoTI-II from Momordica cochinensis & Trypsin inhibitor & Pränting et al. (2010) \\
\hline
\end{tabular}


latex (Van Parijs et al. 1991). This protein inhibits the hyphal growth of fungi by binding to chitin. Other hevein-like proteins with antimicrobial activity have been identified in different plants (Koo et al. 1998; Kiba et al. 2003; Huang et al. 2004; Porto et al. 2012; Table 7). Hevein-like peptides are small (43 amino acid residues) chitin-binding peptides. All known chitinbinding proteins contain a common structural motif of $20-40$ amino acids with several cysteine and glycine residues at conserved positions named the chitin-binding domain, which is responsible for binding the carbohydrate. The hevein-like AMPs differ in the number of disulfide bonds. Most of them possess eight cysteine residues forming four disulfide bonds; for example, hevein homolog isolated from the seeds of Pharabitis nil L. and Avena sativa (Li and Claeson 2003). The other contains only six cysteine residues, as hevein-like proteins from Amaranthus caudatus seeds or Ginkgo biloba (Huang et al. 2000). Only a few hevein-like plant AMPs with ten cysteins have been described. They were isolated from the bark of Eucommia ulmoides Oliv, Euonymus europaeus L. and from seeds of Triticum kiharae (Van den Berg et al. 2002; Huang et al. 2002; Odintsova et al. 2009).

Two AMPs from seeds of Pharbitis nil (Pn-AMP1 and PnAMP2) exhibited potent antifungal activities against both chitin-containing and nonchitin-containing fungi in cell wall. The Pn-AMPs penetrated rapidly into fungal hyphae and caused burst of hyphal tips, disruption of the fungal membrane, and linkage of cytoplasmic materials (Koo et al. 1998).

An antifungal peptide from leaves of G. biloba, designated GAFP, could also cause increased hyphal membrane permeabilization and exhibited antifungal activity towards Fusarium graminearum, Fusarium moniliforme, Pellicularia sasakii Ito, and Alternaria alternata (Huang et al. 2000). The high inhibitory activity of antifungal hevein-type peptides from $T$. kiharae seeds (WAMP-1a and WAMP-1b) was also observed against Fusarium salani, Fusarium oxosporum, Fusarium verticillioides, Neurospora crassa, B. cinerea and Bipolaris sorokiniana, and bacteria C. michiganensis, Erwinia carotovora, and Pseudomonas syringae (Huang et al. 2002).
Table 7 Antimicrobial properties of selected hevein-like AMPs

\begin{tabular}{|c|c|c|}
\hline Hevein-like AMP & Susceptible species & References \\
\hline \multirow[t]{2}{*}{ IWF4 from Beta vulgaris } & Fungi: & \multirow[t]{2}{*}{ Nielsen et al. (1997) } \\
\hline & Cercospora beticola & \\
\hline Ac-AMP1 from Amaranthus caudatus & $\begin{array}{l}\text { Fungi: } \\
\text { Fusarium culmorum }\end{array}$ & $\begin{array}{l}\text { Broekaert et al. } \\
\text { (1992) }\end{array}$ \\
\hline \multirow{11}{*}{$\begin{array}{l}\text { EAFP1 EAFP2 from bark Eucommia ulmoides } \\
\text { bark }\end{array}$} & Fungi: & \multirow[t]{11}{*}{ Huang et al. (2002) } \\
\hline & Phytophthora infestans & \\
\hline & Ascopchyta lycopersici & \\
\hline & Verticillium dahliae & \\
\hline & Giberella zeae & \\
\hline & Alternaria nicotianae & \\
\hline & Fusarium moniliforme & \\
\hline & Fusarium oxysporum & \\
\hline & Colletotrichum gossypii & \\
\hline & Bacteria: & \\
\hline & Pseudomonas syringae & \\
\hline \multirow{2}{*}{$\begin{array}{l}\text { PMAPI from paper mulberry (Broussonetia } \\
\text { papyrifera syn. Morus papyrifera } \text { L.) }\end{array}$} & Fungi: & \multirow[t]{2}{*}{ Zhao et al. (2011) } \\
\hline & Trichoderma viride & \\
\hline \multirow[t]{11}{*}{ WjAMP1 from leaves of Wasabia japonica L. } & Fungi: & \multirow[t]{11}{*}{ Kiba et al. (2003) } \\
\hline & Botrytis cinerea & \\
\hline & Fusarium solani & \\
\hline & Magnaporthe grisea & \\
\hline & Alternaria alternata & \\
\hline & Bacteria: & \\
\hline & Escherichia coli & \\
\hline & Agrobacterium tumefaciens & \\
\hline & Pseudomonascichorii & \\
\hline & $\begin{array}{l}\text { P. plantarii (Burkholderia } \\
\text { plantarii) }\end{array}$ & \\
\hline & P. glumae (B. glumae) & \\
\hline
\end{tabular}




\section{Other plant AMPs}

\section{Ib-AMPs}

Ib-AMPs are the four smallest (20-mer) antifungal and antibacterial peptides isolated from the seeds of Impatiens balsamina. They contain a well-defined loop structure stabilized by two disulfide bonds (Patel et al. 1998).

\section{Knottin-type peptides}

The knottin type antifungal peptides have been isolated from plants Mirabilis jalapa L. (Mj-AMP1) and from Phytolacca americana (PAFP-S; Cammue et al. 1992; Gao et al. 2001). The structure of PAFP-S consists of a triple-stranded, antiparallel beta-sheet with a long loop region connecting $\beta$-strands 1 and 2. This peptide from garden pea (PA1b) acts on insecticides through inhibition of vacuolar ATPase (Chouabe et al. 2011).

\section{$2 \mathrm{~S}$ albumin proteins}

The $2 \mathrm{~S}$ albumin is a water-soluble storage protein group with low molecular weight, rich in glutamine. These proteins have the characteristic molecular weight, cationic residues, and disulfide bonds of antimicrobial peptides. The $2 \mathrm{~S}$ alubmins are encoded by a multigene family, leading to several isoforms that are postranslationally modified, mainly related to proteolytic processes (Candido et al. 2011). The $2 \mathrm{~S}$ albumins are synthesized as a single large precursor polypeptide of $18-21 \mathrm{kDa}$. The processing of the molecule gives rise to two subunits of 8-14 and of 3$10 \mathrm{kDa}$. Structurally, they have four alfa helices and four disulfide bonds as found in the alfa-amylase/trypsin inhibitors and nonspecific lipid transfer proteins. They are widely present in monocotyledonous and dicotyledonous seeds (Candido et al. 2011). Some of these molecules can play a physiological role in plant defense. The heterodimeric antifungal $2 \mathrm{~S}$ albumins have been isolated from the seeds of Malva parviflora, Passiflora edulis f. flavicarpa, and $R$. sativus (Terras et al. 1992; Wang and Bunkers 2000; Agizzio et al. 2003). Furthermore, peptide LJAMP1 from seed extract of matherwort (Leonurus japonicus) with the similar sequence to members of the $2 \mathrm{~S}$ albumin class was identified. The LJAMP1 have activity against the fungi $A$. alternata, Cercospora personata, and Aspergillus niger (Yang et al. 2007). The other protein (MiAMP2) was extracted from seeds of Macadamia integrifolia. MiAMP2 showed antimicrobial activity against a wide variety species of phytopathogenic fungi such as F. oxysporum, Alternaria helianthi, Cetratocystis paradoxa, Cercospora nicotianae, Chalara elegans, Leptosphaeria maculans, Sclerotinia sclerotiorum, Verticillium dahliae, Phytophthora cryptogea, and Phytophthora parasitica nicotianae against the yeast Saccharomyces cerevisiae and phytopathogenic bacteria C. michiganensis, Ralstonia solanacearum, and Escherichia coli (Candido et al. 2011). Nevertheless, the mechanism by which $2 \mathrm{~S}$ proteins inhibit fungal and bacterial growth is not very well understood.

\section{Cell-penetrating peptides}

CPPs, alternatively known as protein transduction domains (PTDs), facilitate the transport of cargoproteins through the cell membrane into live cell (Koren and Torchilin 2012; Milletti 2012). The CPPs are able to penetrate the cell membrane at low micromolar concentrations in vitro and in vivo without using any receptors and without causing any significant membrane damage (Nasrollahi et al. 2012). They can be conjugated with a cargo (nucleic acids, oligonucleotide, peptide sequence, and polisaccharides), efficiently deliver it inside cells and thus are potentially useful agents in drug delivery applications (Greewood et al. 2007; Cascales et al. 2011; Eggenberger et al. 2011). The various CPPs and CPP-cargo conjugates can enter cells using different endocytotic mechanisms (macropinocytosis, clathrin-mediated endocytosis, caveolae/lipid raft-mediated endocytosis, and clathrin/caveolae-independent endocytosis) and can end up in different subcellular compartments (Koren and Torchilin 2012; Milletti 2012). These short, positively charged peptides have different amino acid sequences, but all contain a transduction domain and have 30-100\% cationic Arg and Lys residues (Hong and Su 2011). Even though CPPs have a great sequence variety, it is possible to identify three major classes: cationic, amphipathic, and hydrophobic (Milletti 2012). Such peptides and proteins are derived as partial sequences from transcription factors, bacterial or viral surface proteins, toxins, amphipathic helix-forming peptides, and from ligands of membrane-bound receptors or adhesion proteins. One of the plant CPPs is the sweet arrow peptide which derived from the proline-rich N-terminal repetitive domain of gamma-zei, a storage protein of maize, which has been shown to interact with membrane (Veldhoen et al. 2008). Polyprolines adopt a well-defined helical structure (polyproline II) in water; but unlike $\alpha$-helix, it is lefthanded with 3.0 residues per turn (Fernández-Carneado et al. 2004). For its cellular entry, a clathrin-independent pathway through lipid raft-mediated endocytosis was proposed (Veldhoen et al. 2008). Members of this family are widely present in plants and animals but are absent in yeast. CPPs according to their origin can be grouped into three classes. The first class comprises CPPs originated from naturally occurring proteins, the second consists of "chimeric CPPs" composed of different domains, and the third class contains "model CPPs", which were developed according to structure and function relationships without any homology to natural sequences (Veldhoen et al. 2008). 


\section{Plant AMPs potential for pharmacy and biotechnology}

AMPs are encoded by small genes with conserved sequences; therefore, gene amplification and transgenesis are one of the feasible ways to increase production and enhance specific activity of selected peptides. Therefore, AMPs are also widely applied in the development of transgenic crops.

In many studies, it has been demonstrated that transgenic expression of plant defensins leads to protection of vegetative tissues against pathogen attack (Thomma et al. 2002). For example, the Rs-AFP2 radish defensin was expressed in tobacco and tomato and confers protection against Alternaria longipes (Terras et al. 1995) and Mj-AMP1 jalapa defensin expressed in tomato protects against Alternaria solani (Schaefer et al. 2005). The hevein Pn-AMP expressed in tobacco protects against $P$. parasitica (Koo et al. 2002), and constitutive expression of an alfalfa defensin in potato provided a robust resistance against the agronomically important fungus $V$. dahliae under field conditions (Gao et al. 2000). There are many other examples of such transgenic expression of different plant AMPs (Montesinos 2007). Possibly, the antimicrobial activity of defensins in vivo can even be enhanced due to the synergistic interaction with other defense components (Thomma et al. 2002).

Also thionins are important tools for genetic improvement and development of transgenic plants expressing higher levels of thionins, increasing the pathogenic resistance and reducing crop losses in agriculture, what could lead to decreasing the necessity of enhanced quantities of pesticide used on agriculture (Pelegrini and Franco 2005).

Another example are cyclotides, which have potential applications in both the pharmaceutical and agricultural industries. Cyclotides could be also invaluable in the development of novel antibiotics and bioinsecticides, like kalata B1, where polar and/or charged residues were modified (Clark et al. 2006; Pelegrini et al. 2007).

Cell-penetrating peptides are also highly promising candidates for intracellular drug delivery, RNA, DNA, and nanoparticles in a nondestructive manner. CPPs have been shown to facilitate delivering a wide variety of biomolecules across the skin. The enormous potential of this technology resides in the high efficiency and relatively low toxicity of CPPs conjugated to bioactive cargoes. Different CPPs can be successfully used for the delivery of high molecular weight drugs into cells as well as for vaccine development. The application of CPPs in pharmaceutical formulations is becoming increasingly popular with a great potential in transdermal drug delivery systems (Nasrollahi et al. 2012).

\section{Concluding remarks}

Plant AMPs are diverse peptides differing in their amino acid composition and structure that generally display rapid killing and broad spectrum antimicrobial activities. Therefore, AMPs have a high potential for therapeutic use in healthcare and agriculture, and can be used as natural antibiotics as alternative for their chemical counterparts, for protection of plants, and/or animals against diseases. AMPs offer a good alternative for treating infections in relation to conventional antibiotics based on their broad spectrum activity and efficiency (Pinheiro da Silva and Machado 2012). Despite their many promising features, not one AMP has yet reached the status of a clinically approved drug. However, the cationic AMPs have been applied in the formation of aerosol sprays for patients with cystic fibrosis.

Numerous transgenic plants expressing AMPs that confer different degrees of protection against diseases have been developed; therefore, AMPs could play strong roles in agriculture as plant protection products. Unfortunately, the commercial cultivars have not been marketed because of regulatory limitations and social concerns. The other problems comprise the intrinsic toxicity and low stability of some of the compounds and the need for inexpensive products in plant protection. Therefore, future areas of commercial plant AMPs use consist of developing less toxic and more stable compounds as well as decreasing production costs mainly by improving biotechnological procedures or preparative peptide synthesis (Montesinos 2007).

Acknowledgments The research was supported by National Science Centre grant no. N N405 677740 to B. Kedzia (Institute of Natural Fibres and Medicinal Plants, Poznan, Poland) and National Science Centre grant no. 2011/03/B/NZ9/01335 to R. Nawrot (Adam Mickiewicz University in Poznan, Faculty of Biology, Poland).

Open Access This article is distributed under the terms of the Creative Commons Attribution License which permits any use, distribution, and reproduction in any medium, provided the original author(s) and the source are credited.

\section{References}

Agizzio AP, Carvalho AO, Ribeirosde F, Machado OL, Alves EW, Okorokov LA, Samarao SS, Bloch C, Prates MV, Gomes VM (2003) A 2S albumin-homologous protein from passion fruit seeds inhibits the fungal growth and acidification of the medium by Fusarium oxysporum. Arch Biochem Biophys 416:188-195

Almasia NI, Narhirñak V, Hopp EH, Vazquez-Rovere C (2010) Isolation and characterization of the tissue and developmental specific potato snaking-1 promoter inducible by temperature and wounding. Electr J Plant Biotech. doi:10.2225/vol13-issue5-fulltext-12

Berrocal-Lobo M, Segura A, Moreno M, López G, García-Olmedo F, Molina A (2002) Snakin-2, an antimicrobial peptide from potato whose gene is locally induced by wounding and responds to pathogen infection. Plant Physiol 128:951-961

Bhave M, Morris CF (2008) Molecular genetics of puroindolines and related genes: regulation of expression, membrane binding properties and applications. Plant Mol Biol 66:221-231

Broekaert W, Marien W, Terras F, De Bolle M, Proost P, Van Damme J, Dillen L, Claeys M, Rees SB, Vanderleyden J et al (1992) 
Antimicrobial peptides from Amaranthus caudatus seeds with sequence homology to the cysteine/glycine-rich domain of chitinbinding proteins. Biochemistry 31:4308-4314

Burman R, Strömstedt AA, Malmsten M, Göransson U (2011) Cyclotide-membrane interactions defining factors of membrane binding, depletion and disruption. Biochim Biophys Acta 1808: 2665-2673

Cammue BP, De Bolle MF, Terras FR, Proost P, Van Damme J, Rees SB, Vanderleyden J, Broekaert WF (1992) Isolation and characterization of a novel class of plant antimicrobial peptides form Mirabilis jalapa $L$ seeds. J Biol Chem 267:2228-2233

Cammue B, Thevissen K, Hendricks M, Eggermont K, Goderis IJ, Proost P, Van Damme J, Osborn RW, Guerbette F, Kader JC et al (1995) A potent antimicrobial protein of onion seeds showing sequence homology to plant lipid transfer proteins. Plant Physiol 109:445-455

Cândido Ede S, Pinto MF, Pelegrini PB, Lima TB, Silva ON, Pogue R, Grossi-de-Sá MF, Franco OL (2011) Plant storage proteins with antimicrobial activity: novel insights into plant defense mechanisms. FASEB J 25:3290-3305

Cascales L, Henriques ST, Kerr MC, Huang YH, Sweet MJ, Daly NL, Craik DJ (2011) Identification and characterization of a new family of cell penetrating peptides. J Biol Chem 286:36932-36943

Chandrashekhara NRS, Deepak S, Manjunath G, Shetty SH (2010) Thionins (PR protein 13) mediate pearl millet down mildew disease resistance. Arch Phytopathol Plant Protect 43:1356-1366

Charnet P, Molle G, Marion D, Rousset M, Lullien-Pellerin V (2003) Puroindolines form ion channeles in biological membranes. Biophys J 84:2416-2426

Cheng CS, Chouabe C, Eyraud V, Rahioui I, Royer C, Soulage C, Bonvallet R, Huss M, Gressent F (2011) New mode of action for a knottin protein bioinsecticide pea albumin 1 subunit $\mathrm{b}(\mathrm{PA} 1 \mathrm{~b})$ is the first peptidic inhibitor of V-ATP-ase. J Biol Chem 286:36291-36296

Choi KY, Chow LN, Mookherjee N (2012) Cationic host defence peptides: multifaceted role in immune modulation and inflammation. J Innate Immun 4:361-370

Chouabe C, Eyraud V, Da Silva P, Rahioui I, Royer C, Soulage C, Bonvallet R, Huss M, Gressent F (2011) New mode of action for a knottin protein bioinsecticide: pea albumin 1 subunit $\mathrm{b}$ (PA1b) is the first peptidic inhibitor of V-ATPase. J Biol Chem 286:36291-36296

Clark RJ, Daly NL, Craik DJ (2006) Structural plasticity of the cycliccystine-knot framework: implications for biological activity and drug design. Biochem J 394:85-93

Colgrave ML, Craik DJ (2004) Thermal, chemical, and enzymatic stability of the cyclotide kalata B1 the importance of the cyclic cystine knot. Biochemistry 43:5965-5975

Craik DJ (2010) Discovery and applications of plant cyclotides. Toxicon 57:1092-1102

Craik DJ (2012) Host-defense activities of cyclotides. Toxins 4:139-156

Craik DJ, Daly NL, Bond T, Waine C (1999) Plant cyclotides. A unique family of cyclic and knotted proteins that defines the cyclic cystine knot structural motif. J Mol Biol 294:1327-1336

Craik DJ, Cemazar M, Wang CK, Baly NL (2006) The cyclotide family of circular miniproteins nature's combinatorial peptide template. Biopolymers 84:250-266

Daly NL, Gustafson KR, Craik DJ (2004) The role of the cyclic peptide backbone in the anti-HIV activity of the cyclotide kalata B1. FEBS Lett 574:69-72

De Beer A, Viver MA (2011) Four plant defensins from an indigenous South African Brassicaceae species display divergent activities against two test pathogens despite high sequence similarity in the encoding genes. BMC Res Notes 4:459-476

De Lucca AJ, Jacks T, Broekaert W (1999) Fungicidal and binding properties of three plant peptides. Mycopathologia 40:87-91

De Lucca AJ, Cleveland TE, Wedge DE (2005) Plant-derived antifungal proteins and peptides. Can J Microbiol 51:1001-1014
Dhatwalia VK, Sati OP, Tripathi MK, Kumar A (2009) Isolation, characterization and antimicrobial activity at diverse dilution of wheat puroindoline protein. World J Agric Sci 5:297-300

Diz MS, Carvalho AO, Ribeiro SF, Da Cunha M, Beltramini L, Rodrigues R, Nascimento VV, Machado OL, Gomez V (2011) Characterisation, immunolocalisation and antifungal activity of a lipid transfer protein from chili pepper (Capsicum annuum) seeds with novel $\alpha$-amylase inhibitory properties. Physiol Plant 142:233-246

Dubreil L, Gabroit T, Bouchet B, Gallant DJ, Broekaert WF, Quillien L, Marion D (1998) Spatial and temporal distribution of the major isoforms of puroindolines (puroindoline-a and puroindoline-b) and non-specific lipid transfer protein nsLTPe1) of Triticum aestivum seeds relationships with their in vitro antifungal properties. Plant Sci 138:121-135

Eggenberger K, Mink C, Wadhwani P, Ulrich AS, Nick P (2011) Using the peptide BP100 as a cell-penetrating tool for the chemical engineering of actin filaments within living plants cell. Chembiochem 12:132-137

Egger M, Hauser M, Mari A, Ferreira F, Gadermaier G (2010) The role of lipid transfer proteins in allergic diseases. Curr Allergy Asthma Rep 10:326-335

Epple P, Apel K, Bohlmann H (1995) An Arabidopsis thaliana thionin gene is inducible via a signal transduction pathway different from that for pathogenesis-related proteins. Plant Physiol 109:813-820

Eudes F, Chugh A (2008) Cell penetrating peptides. From mammalian to plant cells. Plant Signal Behav 3:549-550

Fernandez De Caleya R, Gonzales-Pascual B, Garcia-Olmedo F, Carbonero P (1972) Suseptibility of phytopathogenic bacteria to wheat purothionins in vitro. Appl Microbiol 23:998-1000

Fernández-Carneado J, Kogan MJ, Castel S, Giralt E (2004) Potential peptide carriers: amphipathic proline-rich peptides derived from the $\mathrm{N}$-terminal domain of gamma-zein. Angew Chem Int Ed Engl 43: 1811-1814

Gao A, Hakimi SM, Mittanck CA et al (2000) Fungal pathogen protection in potato by expression of a plant defensin peptide. Nat Biotechnol 18:1307-1310

Gao GH, Liu W, Dai JX, Wang JF, Hu Z, Zhang Y, Wang DC (2001) Solution structure of PAFP-S a new knottin-type antifungal peptide from the seeds of Phytolacca americana. Biochemistry 40:1097310978

Gautier MF, Aleman ME, Guirao A, Marion D, Joudrier P (1994) Triticum aestivum puroindolines, two basic cysteine-rich seed proteins, DBA sequence analysis and developmental gene expression. Plant Mol Biol 25:43-57

Giroux MJ, Sripo T, Gerhardt S, Sherwood J (2003) Puroindolines. Their role in grain hardness and plant defense. Biotechnol Genet Eng Rev 20:276-290

Giudici AM, Regente MC, Villalain J, Pfuller K, Pfuller U, de la Canal L (2004) Misctletoe viscotoxins induce membrane permeabilization and spore death in phytopathogenic fungi. Physiol Plant 121:2-7

Greewood KP, Daly NL, Brown DL, Stow JL, Craik DJ (2007) The cyclic cystine knot miniprotein MCoTI-II is internalized into cells by macropinocytosis. Int J Biochem Cell Biol 39:2252-2264

Gruber CW (2010) Global cyclotide adventure: a journey dedicated to the discovery of circular peptides from flowering plants. Biopolymers 94:565-572

Gustafson KR, Sowder RCI, Henderson LE, Parsons IC, Kashman Y, Cardellina JHI, McMahon JB, Buckheit RWJ, Pannell LK, Boyd MR, Cirulins A and B (1994) Novel HIV-inhibitory macrocyclic peptides from the tropical tree Chassalia parvifolia. J Am Chem Soc 116:9337-9338

Hammami R, Ben Hamida J, Vergoten G, Fliss I (2009) PhytAMP: a database dedicated to antimicrobial plant peptides. Nucleic Acid Res 37:D963-D968

Hegedus N, Marx F (2013) Antifungial proteins: more than antimicrobials? Fungal Biol Rev 26:132-145 
Hong M, Su Y (2011) Structure and dynamics of cationic membrane peptides and proteins insights from solid-state NMR. Protein Sci 20: $641-655$

Huang X, Xie W, Gong Z (2000) Characteristics and antifungal activity of a chitin binding protein from Ginkgo biloba. FEBS Lett 478:123-126

Huang RH, Xiang Y, Liu XZ, Zhang Y, Hu Z, Wang DC (2002) Two novel antifungal peptides distinct with a five-disulfide motif from the bark of Eucommia ulmoides Oliv. FEBS Lett 521:87-90

Huang RH, Xiang Y, Tu GZ, Zhang Y, Wang DC (2004) Solution structure of Eucommia antifungal peptide a novel structural model distinct with a five-disulfide motif. Biochemistry 43:6005-6012

Hughes P, Dennis E, Whitecross M, Liewelly D, Gage P (2000) The cytotoxic plant protein, $\beta$-purothionin, forms ion channels in lipid membranes. J Biol Chem 14:823-827

Ireland DC, Clark RJ, Daly NL, Craik DJ (2010) Isolation, sequencing, and structure-activity relationships of cyclotides. J Nat Prod 73: $1610-1622$

Jennings C, West J, Waine C, Craik D, Anderson M (2001) Biosynthesis and insecticidal properties of plant cyclotides. The cyclic knotted proteins from Oldenlandia affinis. Proc Natl Acad Sci U S A 98: 8913-8919

Jing W, Demcoe A, Vogel HJ (2003) Conformation of bactericidal domain of puroindoline a structure and mechanism of action of a 13 residue antimicrobial peptide. J Bacteriol 185:4938-4947

Kiba A, Saitoh H, Nishihara M, Omiya K, Yamamura S (2003) Cterminal domain of a hevein-like protein from Wasabia japonica has potent antimicrobial activity. Plant Cell Physiol 44:296-303

Kirubakaren SI, Begum SM, Ulganathan K, Sakthivel N (2008) Characterization of a new antifungal lipid transfer protein from wheat. Plant Physiol Biochem 46:918-927

Koo JC, Lee SY, Chun HJ, Cheong YH, Choi JS, Kawabata S, Miyagi M, Tsunasawa S, Ha KS, Bae DW, Han CD, Lee Blcho MJ (1998) Two hevein homologs isolated from the seed of Pharbitis nil L exhibit potent antifungal activity. Biochim Biophys Acta 1382:80-90

Koo JC, Chun HJ, Park HC et al (2002) Over-expression of a seed specific hevein-like antimicrobial peptide from Pharbitis nil enhances resistance to a fungal pathogen in transgenic tobacco plants. Plant Mol Biol 50:441-452

Koren E, Torchilin VP (2012) Cell-penetrating peptides: breaking through to the other side. Trends Mol Med 18:385-393

Kragh K, Nielsen J, Nielsen KK, Dreboldt S, Mikkelsen JD (1995) Characterization and localization of new antifungal cysteine-rich proteins from Beta vulgaris. Mol Plant Microbe Interact 8:579-585

Lai Y, Gallo RL (2009) AMPed immunity how antimicrobial peptides have multiple roles in immune defense. Trends Immunol 30:131-141

Lay FT, Anderson MA (2005) Defensins - components of the innate immune system in plants. Curr Protein Pept Sci 6:85-101

Li SS, Claeson P (2003) Cys/Gly-rich proteins with a putative single chitin-binding domain from oat (Avena sativa) seeds. Phytochemistry 63:249-255

Li C, Xie W, Wang L, Zhao Y (2011) The phosphorylation of lipid transfer protein CaMBP10. Protein Pept Lett 18:17-22

Majewski J, Stec B (2001) X-ray scattering studies of model lipid membrane interacting with purothionins provide support for a previously proposed mechanism of membrane lysis. Eur Biophys J 39:1155-1165

Mak AS, Jones BL (1976) The amino sequence of wheat $\beta$-purothionin. Can J Biochem 54:835-842

Marion D, Bakan B, Elmorjani K (2007) Plant lipid binding proteins properties and applications. Biotechnol Adv 25:195-197

Milbradt A, Kerek F, Moroder L, Renner C (2003) Structural characterization of hellethionins from Helleborus purpurascens. Biochemistry 42:2404-2411

Milletti F (2012) Cell-penetrating peptides: classes, origin, and current landscape. Drug Discov Today 17:850-860

Miteva M, Andersson M, Karshikoff A, Otting G (1999) Molecular electroporation: a unifying concept for the description of membrane pore formation by antibacterial peptides, exemplified with NKlysin. FEBS Lett 462(1-2):155-158

Molina A, Segura A, Garcia-Olmedo F (1993) Lipid transfer proteins (nsLTPs) from barley and maize leaves are potent inhibitors of bacterial and fungal plant pathogens. FEBS Lett 316:119-122

Montesinos E (2007) Antimicrobial peptides and plant disease control. FEMS Microbiol Lett 270:1-11

Mylne JS, Wang CK, van der Weerden NL, Craik DJ (2010) Cyclotides are a component of the innate defense of Oldenlandia affinis. Biopolymers 94:635-646

Nahirñak V, Almasia NI, Hopp HE, Vazquez-Rovere C (2012) Snakin/ GASA proteins involvement in hormone crosstalk and redox homeostasis. Plant Signal Behav 7:1004-1008

Nasrollahi SA, Taghibiglou C, Azizi E, Farboud ES (2012) Cellpenetrating peptides as a novel transdermal drug delivery system. Chem Biol Drug Des 80:639-646

Ngai PH, Ng TB (2005) Phaseococcin, an antifungal protein with antiproliferative and anti-HIV-1 reverse transcriptase activities from small scarlet runner beans. Biochem Cell Biol 83:212220

Nielsen KK, Nielsen JE, Madrid SM, Mikkelsen JD (1997) Characterization of a new antifungal chitin-binding peptide from sugar beet leaves. Plant Physiol 113:83-91

Oard S, Rush MC, Oard JH (2004) Characterization of antimicrobial peptides agains a US strain of the rice pathogen Rhizoctonia solani. J Appl Microbiol 97:169-180

Odintsova TI, Vassilevski AA, Slavokhotova AA, Musolyamov AK, Finkina EI, Khadeeva NV, Rogozhin EA, Korostyleva TV, Pukhalsky VA, Grishin EV, Egorov TA (2009) A novel antifungal hevein-type peptide from Triticum kiharae seeds with a unique 10cysteine motif. FEBS J 276:4266-4275

Oomen RJ, Séveno-Carpentier E, Ricodeau N, Bournaud C, Conéjéro G, Paris N, Berthomieu P, Marquès L (2011) Plant defensin AhPDF1 is not secreted in leaves but it accumulates in intracellular compartments. New Phytol 192:140-150

Ovesen RG, Brandt KK, Goransson U, Nilesen J, Hansen HC, Cedergreen N (2011) Biomedicine in the environment: cyclotides constitute potent natural toxins in plants and soil bacteria. Environ Toxicol Chem 30:1119-1196

Padovan L, Segat L, Tossi A, Calsa TJR, Ederson AK, Brandao L, Guimarães RL, Pandolfi V, Pestana-Calsa MC, Belarmino LC, Benko-Iseppon AM, Crovella S (2010) Characterization of a new defensin from cowpea (Vigna unguiculata (L) Walp). Protein Pept Lett 17:297-304

Patel SU, Osborn R, Rees S, Thornton JM (1998) Structural studies of Impatiens balsamina antimicrobial protein (Ib-AMP1). Biochemistry 37:983-990

Pelegrini PB, Franco OL (2005) Plant gamma-thionins: novel insights on the mechanism of action of amulti-functional class of defense proteins. Int J Biochem Cell Biol 37:2239-2253

Pelegrini PB, Quirino BF, Franco OL (2007) Plant cyclotides: an unusual class of defense compounds. Peptides 28:1475-1481

Pelegrini PB, Del Sarto RP, Silva ON, Franco OL, Grossi-De-Sa MF (2011) Antibacterial peptides from plants: what they are and how they probably work. Biochem Res Int. doi:10.1155/2011/250349

Pestana-Calsa MC, Calsa T (2011) In silico identification of plant-derived antimicrobial peptides. DOI:. doi:10.5772/21172, www.intechopen. com

Pettersen EF, Goddard TD, Huang CC, Couch GS, Greenblatt DM, Meng EC, Ferrin TE (2004) UCSF Chimera - a visualization system for exploratory research and analysis. J Comput Chem 25(13):16051612

Pinheiro da Silva F, Machado MC (2012) Antimicrobial peptides: clinical relevance and therapeutic implications. Peptides 36:308-314

Plan MR, Saska I, Cagauan AG, Craik DJ (2008) Backbone cyclised peptides from plants show molluscidal activity against the rice pest 
Pomacea canaliculata (golden appl snail). J Agric Food Chem 56: 5237-5241

Pokorny A, Almeida PF (2004) Kinetics of dye efflux and lipid flip-flop induced by delta-lysin in phosphatidylcholine vesicles and the mechanism of graded release by amphipathic, alpha-helical peptides. Biochemistry 43(27):8846-8857

Portieles R, Ayra C, Gonzalez E, Gallo A, Rodriguez R, Chacón O, López Y, Rodriguez M, Castillo J, Pujol M, Enriquez G, Borroto C, Trujillo L, Thomma BP, Borrás-Hidalgo O (2010) NmDef02:a novel antimicrobial gene isolated from Nicotiana megalosiphon confers high level pathogen resistance under greenhouse and field conditions. Plant Biotechnol J 8:678-690

Porto WF, Souza VA, Nolasco DO, Franco OL (2012) In silico identification of novel hevein-like peptide precursors. Peptides 38:127-136

Pränting M, Lööv C, Burman R, Göransson U, Andersson DI (2010) The cyclotide cycloviolacin $\mathrm{O} 2$ from Viola odorata has potent bactericidal activity against Gram-negative bacteria. J Antimicrob Chemother 65:1964-1971

Rayapuram C, Wu J, Haas C, Baldwin IT (2008) PR-13/Thionin but not PR-1 mediates bacterial resitance in Nicotiana attenuata in nature, and neither influences herbivore resistance. Mol Plant Microbe Interact 21:988-1000

Rivas L, Luque-Ortega J, Fernandez-Reyes M, Andreu D (2010) Membrane-active peptides as ant- infectious agents. J Appl Biomed 8:159-167

Rogozhin EA, Oshchepkova YI, Odintsova TI, Khadeeva NV, Veshkurova ON, Egorov TA, Grishin EV, Salikhov SI (2011) Novel antifungal defensins from Nigella sativa L. seeds. Plant Physiol Biochem 49:131-137

Samuelsson G, Pettersson B (1970) Separation of viscotoxins from the European mistletoe Viscum album L. (Loranthaceae) by chromatography on sulfoethyl Sephadex. Acta Chem Scand 24:2751-2756

Samuelsson G, Pettersson BM (1977) Toxic protein from the mistletoe Dendrophtora clavata. II. The amino acid sequence of denclatoxin B. Acta Pharm Suec 14:245-254

Schaefer SC, Gasic K, Cammue B, Broekaert W, van Damme EJM, Peumans WJ, Korban SS (2005) Enhanced resistance to early blight in transgenic tomato lines expressing heterologous plant defense genes. Planta 222:858-866

Schauber J, Dorschner RA, Yamasaki K, Brouha B, Gallo RL (2006) Control of the innate epithelial antimicrobial response is cell-type specific and dependent on relevant microenvironmental stimuli. Immunology 118:509-519

Schrader-Fisher G, Apel K (1994) Organ specific expression of highly divergent thionin variants that are distinct from the seed-specific crambin in the crucifer Crambe abyssinica. Mol Gen Genet 245: 380-389

Segura A, Moreno M, García-Olmedo F (1993) Purification and antipathogenic activity of lipid transfer proteins (LTPs) from the leaves of Arabidopsis and spinach. FEBS Lett 332:243-246

Segura A, Moreno M, Molina A, García-Olmedo F (1998) Novel defensin subfamily from spinach (Spinacia oleracea). FEBS Lett 435:159-162

Segura A, Moreno M, Madueño F, Molina A, García-Olmedo F (1999) Snakin-1, a peptide from potato that is active against plant pathogens. Mol Plant Microbe Interact 12:16-23

Selitrennikoff CP (2001) Antifungal proteins. Appl Envirol Microbiol 67: 2883-2894

Spelbrink RG, Dilmac N, Allen A, Smith TJ, Shah DM, Hockerman GH (2004) Differential antifungal and calcium channel blocking activity among structurally related plant defensins. Plant Physiol 135:20552067

Stec B (2006) Plant thionins - the structural perspective. Cell Mol Life Sci 63:1370-1385

Stotz HU, Thomson JG, Wang Y (2009) Plant defensins defense, development and application. Plant Signal Behav 11:1010-1012
Svangård E, Burman R, Gunasekera S, Lövborg H, Gullbo J, Göransson U (2007) Mechanism of action of cytotoxic cyclotides cycloviolacin $\mathrm{O} 2$ disrupts lipid membranes. J Nat Prod 70:643-647

Terras FR, Schoofs HM, De Bolle MF, Van Leuven F, Rees SB, Vanderleyden J, Cammue BP, Broekaert WF (1992) Analysis of two novel classes of plant antifungal proteins from radish (Raphanus sativus L.) seeds. J Biol Chem 267:15301-15309

Terras F, Schoofs H, Thevissen K, Osborn RW, Vanderleyden J, Cammue B, Broekaert WF (1993a) Synergistic enhancement of the antifungal activity of wheat and barley thionins by radish and oilseed rape $2 \mathrm{~S}$ albumins and by barley trypsin inhibitors. Plant Physiol 103:13111319

Terras FR, Torrekens S, Van Leuven F, Osborn RW, Vanderleyden J, Cammue BP, Broekaert WF (1993b) A new family of basic cysteine-rich plant antifungial proteins from Brassicaceae species. FEBS Lett 316:233-240

Terras FR, Eggermont K, Kovaleva V et al (1995) Small cysteine-rich antifungal proteins from radish: their role in host defense. Plant Cell 7:573-588

Thevissen K, Ghazi A, de Samblanx GW, Brownlee C, Osborn RW, Broekaert WF (1996) Fungal membrane responses induced by plant defensins and thionins. J Biol Chem 271:15018-15025

Thevissen K, Warnecke DC, François IE, Leipelt M, Heinz E, Ott C, Zähringer U, Thomma BP, Ferket KK, Cammue BP (2004) Defensins from insects and plants interact with fungal glucosylceramides. J Biol Chem 279:3900-3905

Thevissen K, Kristensen HH, Thomma BP, Cammue BP, Francois IE (2007) Therapeutic potential of antifungal plant and insect defensins. Drug Discov Today 12:966-971

Thevissen K, De Mello TP, Xu D, Blankenship J, Vandenbosch D, Idkowiak-Baladys J, Govaert G, Bink A, Rozental S, de Groot PW, Davis TR, Kumamoto CA, Vargas G, Nimrichter L, Coenye T, Mitchell A, Roemer T, Hannun YA, Cammue BP (2012) The plant defensin RsAFP2 induces cell wall stress, septin mislocalization and accumulation of ceramides in Candida albicans. Mol Microbiol 84:166-180

Thomma BP, Cammue BP, Thevissen K (2002) Plant defensins. Planta 216:193-202

Thongyoo P, Bonomelli C, Leatherbarrow RJ, Tate EW (2009) Potent inhibitors of beta-tryptase and human leucocyte elastase based on the MCoTI-II scaffold. J Med Chem 52:61976200

Thunberg E, Samuelsson G (1982) Isolation and properties of ligatoxin A, a toxic protein from the mistletoe Phoradendron liga. Acta Pharm Suec 19:285-292

Van den Berg KP, Proost P, Van Damme J, Coosemans J, van Damme EJ, Peumans WJ (2002) Five disulfide bridges stabilize a hevein-type antimicrobial peptide from the bark of spindle tree (Euonymus europaeus L. ). FEBS Lett 530:181-185

Van der Weerden NL, Hancock RE, Anderson MA (2010) Permeabilization of fungal hyphae by the plant defensin $\mathrm{NaD} 1$ occurs through a cell wall-dependent process. J Biol Chem 285: 37513-37520

Van Parijs J, Broekaert WF, Goldstein IJ, Peumans WJ (1991) Hevein an antifungal protein from rubber-tree (Hevea braziliensis) latex. Planta 183:258-264

Veldhoen S, Laufer SD, Restle T (2008) Recent developments in peptidebased nucleic acid delivery. Int J Mol Sci 9:1276-1320

Vernon LP (1992) Pyrularia thionin physical properties, biological response and comparison to other thionins and cardiotoxin. J Toxicol 11:169-191

Villa-Perello M, Sanchez-Vallet A, Garcia-Olmedo F, Molina A, Andreu D (2003) Synthetic and structural studies on Pyrularia pubera thionin: a single-residue mutation enhances activity against Grampositive bacteria. FEBS Lett 536:215-219 
Wang X, Bunkers GJ (2000) Potent heterologous antifungal proteins from cheeseweed (Malva parviflora). Biochem Biophys Res Commun 279:669-673

Wijaya R, Neumann GM, Condron R, Hughes AB, Polya GM (2000) Defense proteins from seed of Cassia fistula include a lipid transfer protein homologue and a protease inhibitory plant defensin. Plant Sci 159:243-255

Wong JH, Ng TB (2005) Sesquin, a potent defensin-like antimicrobial peptide from ground beans with inhibitory activities toward tumor cells and HIV-1 reverse transcriptase. Peptides 26:1120-1126

Wu M, Maier E, Benz R, Hancock RE (1999) Mechanism of interaction of different classes of cationic antimicrobial peptides with planar bilayers and with the cytoplasmic membrane of Escherichia coli. Biochemistry 38(22):7235-7242

Yang X, Xiao Y, Wang X, Pei Y (2007) Expression of a novel small antimicrobial protein from the seeds of motherwort (Leonurus japonicus) confers disease resistance in tobacco. Appl Environ Microbiol 73:939-946
Yeats TH, Rose JKC (2008) The biochemistry and biology of extracellular plant lipid-transfer proteins (LTPs). Protein Sci 17:191-198

Yount NY, Yeaman MR (2013) Peptide antimicrobials: cell wall as a bacterial target. Ann N Y Acad Sci 1277:127-138

Zhang J, Martin JM, Balint-Kurti P, Huang L, Giroux MJ (2011) The heat puroindoline genes confer fungal resistance in transgenic corn. J Phytopathol 159:188-190

Zhao M, Ma Y, Pan YH, Zhang CH, Yuan WX (2011) A hevein-like protein and a class I chitinase with antifungal activity from leaves of the paper mulberry. Biomed Chromatogr 25:908-912

Zhu YJ, Agbayani R, Moore PH (2007) Ectopic expression of Dahlia merckii defensin DmAMP1 improves papaya resistance to Phytophthora palmivora by reducing pathogen vigor. Planta 226:87-97

Zottich U, Da Cunha M, Carvalho AO, Dias GB, Silva NC, Santos IS, Do Nacimento VV, Miguel EC, Machado OL, Gomes VM (2011) Purification, biochemical characterization and antifungal activity of a new lipid transfer protein (LTP) from Coffea canephora seeds with $\alpha$-amylase inhibitor properties. Biochim Biophys Acta 4:375-383 